\title{
Periodic Interval Data Type
}

National Cancer Institute

\section{Source}

National Cancer Institute. Periodic Interval Data Type. NCI Thesaurus. Code C95672.

A data type comprised of an interval of time that occurs intermittently. 